\title{
POTENTIAL OF BIOLOGICAL MORTAR FOR MICRO-CRACK REMEDIATION OF CALCAREOUS STONES IN HISTORICAL MONUMENTS
}

\section{BIYOLOJIK HARÇ KULLANIMININ TARIHII ANITLARIN KALKERLI TAŞLARINDAKI MIKRO-ÇATLAKLARI IYILEŞTIRME POTANSIYELI}

\author{
Makale Bilgisi Article Info \\ Başvuru: 25 Kasım 2021 Received: November 25, 2021 \\ Hakem Değerlendirmesi: 26 Kasım 2021 Peer Review: November 26, 2021 \\ Kabul: 11 Aralık 2021 Accepted: December 11, 2021
}

DOI : 10.22520/tubaked2021.24.012

\section{Elif SIRT CIPLAK * - KIvanç BILECEN ** Kiraz Göze AKOĢLU *** - Neriman ŞAHIN GÜÇHAN ****}

\begin{abstract}
Since the early ages, first human beings, then architects and civil engineers have preferred stones for the construction of historic monuments and buildings due to their durable nature. But in the course of time, these stones have inescapably been faced with different kinds of weathering processes because of several biotic and abiotic weathering factors. In calcareous stones, micro-cracks/fissures are the common deterioration forms resulting from these weathering processes, and in the long term, they affect the durability of the structure. The survival of monuments and buildings is substantially related with the protection and the conservation of the materials from which they are constructed. To this end, several treatment approaches have been developed for the micro-crack remediation of these materials but there is still room for improvement to fulfill multiple aspects of remediation studies. Although many studies and applications can be found on biomineralization techniques and approaches, few studies have been conducted on biological mortars. This review highlights the potential of biological mortar acquired through biomineralization as an alternative bio-based repair material for the healing of micro-cracks of historic calcareous stones. Promising findings from laboratory analyses and field observations of biological mortars are given with a brief discussion on limitations, challenges, and future works in relation with remediation of micro-cracks of stones.
\end{abstract}

Keywords: Biomineralization, bacteria, biological mortar (BM), conservation, cultural heritage, micro-cracks, calcareous stones.

Öğr. Gör. Dr., Kültürel Mirası Koruma Lisansüstü Programı, Mimarlık Fakültesi, ODTÜ, 06800 Ankara, Türkiye.

e-posta: selif@metu.edu.tr ORCID: 0000-0002-6800-6236

** Doç. Dr., Moleküler Biyoloji ve Genetik Bölümü, Konya Gıda ve Tarım Üniversitesi, 42080 Konya, Türkiye. e-posta: kivanc.bilecen@gidatarim.edu.tr

*** Dr., Bağımsız araştırmacı, Abu Dabi, BAE.

e-posta: gozester@gmail.com ORCID: 0000-0002-6254-3516

ORCID: 0000-0003-3645-1594

**** Prof. Dr., Kültürel Mirası Koruma Lisansüstü Programı, Mimarlık Fakültesi, ODTÜ, 06800 Ankara, Türkiye. e-posta: neriman@metu.edu.tr

ORCID: 0000-0001-7841-9344 


\section{ÖZET}

İlk çağlardan beri önce insanoğlu daha sonra mimarlar ve inşaat mühendisleri, tarihi anıtların ve binaların yapımında, dayanıklı olmalarından dolayı taşları tercih etmişlerdir. Ancak zaman içerisinde bu taşlar çeşitli biyotik ve abiyotik bozulma faktörleri nedeniyle kaçınılmaz olarak farklı türdeki bozulma süreçlerine maruz kalmışlardır. Kalkerli taşlarda gözlemlenen mikro-çatlaklar bu ayrışma süreçlerinden kaynaklanan yaygın bozulma biçimleridir ve uzun vadede yapının dayanıklılı̆ı̆ını etkilemektedirler. Anıtların ve binaların hayatta kalması, büyük ölçüde inşa edildiği malzemelerin korunması ile ilgilidir. Bu amaçla, malzemelerde oluşan mikro-çatlakların iyileştirilmesi için çeşitli müdahale yaklaşımları geliştirilmiştir, ancak hiçbiri hedeflenen iyileştirme performansını tüm yönleriyle yerine getirememiştir. Öte yandan biyomineralizasyon teknikleri ve yaklaşımları üzerine pek çok çalışma ve uygulama bulunabilmesine rağmen biyolojik harç konusu üzerine çok az çalışma yapılmıştır. Bu derleme, tarihi kalkerli taşların mikro-çatlaklarının iyileştirilmesi için biyomineralizasyondan türevlenen, alternatif bir biyolojik tabanlı onarım malzemesi olan biyolojik harcın kullanım potansiyeline dikkat çekmektedir. Biyolojik harçların laboratuvar analizlerinden ve saha gözlemlerinden elde edilen umut verici bulgular özet bir tartışma olarak kısıtlamalar, zorluklar ve taşlardaki mikro-çatlakların iyileştirilmesi ile ilgili gelecekte yapılabilecek çalışmalar ile birlikte verilmektedir.

Anahtar Kelimeler: Biyomineralizasyon, bakteri, biyolojik harç, koruma, kültürel miras, mikro-çatlak, kalkerli taşlar. 


\section{INTRODUCTION}

Calcareous stones, as they are moderately durable and available, have widely been used in the construction of historic monuments and buildings. However, in the long run, they have been facing different kinds of weathering processes because of the combined action of changing weather conditions, biological agents, air pollution, soluble salts, etc. Eventually, these weathering processes may cause physical, chemical, mechanical, and microstructural changes resulting in cracks, deformations, detachments, material losses, discolorations, deposits, and biological colonization in stones (Cartwright et al., 2008).

Among these deterioration patterns, micro-cracks and fissures may not be seen as important, but in the course of time, they can propagate and lead to larger cracks. Clay swelling, calcite thermal expansion, freeze/thaw damage, salt crystallization, and biological activities are important weathering factors that can create stress in stone either by initiating or propagating these cracks (McNabb, 2012). In addition, weak zones or cavities near the surface are the places for initial fissure formations as the materials are carried away from these regions and later these cavities turn into larger cracks on the sedimentary rocks with the continuation of the dissolving process (Abd El Aal, 2017).

Numerous conservation treatments have been applied to stop or at least slow down these deterioration processes. Organic and inorganic consolidants such as epoxy resins, silanes, tetra-silanes (Doehne et al., 2010) and $\mathrm{Ba}(\mathrm{OH}) 2$ (Lewin \& Baer, 1974) have been applied but they have often been reported to have a pore-blocking effect, poor penetration and harmful surface films afterwards (Rodriguez-Navarro et al., 2003). Furthermore, they reduce aesthetic appearance due to color and texture incompatibility and need constant maintenance (Jagadeesha Kumar et al., 2013). On the other hand, nano lime technology derived from lime wash applications is currently available after some years of development. Even the technique represented better results than any other consolidants, long-term testing and further development of nano-lime materials is necessary because it has still some disadvantages as; formation of white haze on the treated surface, quick evaporation or over saturation of the solvent, insufficient strength (Borsoi, 2017) and its efficiency in the presence of soluble salts has not yet been studied in detail. As surface detachments and crack formations propagate, repair mortars have been used to prevent water uptake and weathering agents through the cavities and cracks of stones. Cement mortar has been used for the repair of cracks of stone even though its proven drawbacks as swelling of dissoluble minerals (Minto et al., 2018); incompatibility with the original material-stone (Palomo et al., 2002); formation of soluble salts (Pacheco-Torgal et al., 2012). Moreover, dangerous gases released during the curing of this material cause significant environmental health hazards (Hansen et al., 2003). Lime-based repair materials designed for the needs of the historic monuments are more preferable to any cement-based product for a long while. Since they show significant compatibility with the original material, a large number of studies have been conducted in the field of lime mortars and lime-based conservation materials (Böke et al., 2008; Klisińska-Kopacz et al., 2010; Schueremans et al., 2011; Veiga et al., 2009). Even the capacity of lime-based mortars for filling voids, gaps, and micro-cracks is not satisfying; they are still preferred in conservation treatments to prevent further and more serious deteriorations.

In the last two decades, with the rising interest in green conservation materials, biomineralization approach has been investigated and applied widely for the consolidation of historic stones. In this technique, a material-microbial carbonate, that is remarkably similar to the original surface is formed as a protective coating by the activity of calcite precipitating bacteria. On the other hand, when a filler material is required for remediation of micro-cracks, biological mortar (BM), has been developed as an alternative technique in order to increase the compatibility of repair materials, ease intervention for soft stones (Orial et al., 2003) and reduce the ecological impact by being an environmentally-friendly repair material. This technique also relies on bacterially induced calcium carbonate precipitation but produced microbial carbonate acts as binding of aggregates in BM.

Even though microbially induced calcite precipitation (MICP) was used early on for consolidation treatments of historical stones (Adolphe et al., 1990; Boquet et al., 1973), current studies using bacterial agents are mostly focused on remediation of micro-cracks of concrete and Portland cement (Annamalai et al., 2013; Castro-Alonso et al., 2019; De Muynck et al., 2010a; Jonkers, 2011; Ramachandran et al., 2001). Therefore, in this review, BM has been discussed as a promising repair material for remediation of microcracks of historical calcareous stones considering the development process, methodology, performance, limitations, and challenges to reveal its potential for future researches. 


\section{BIOMINERALIZATION}

Since the biomineralization process is the core in $\mathrm{BM}$ production, (Adolphe et al., 1990; Orial et al., 2003), biomineralization processes as well as their applications in the field of protection, and conservation of cultural heritage are given with a short overview.

\section{Microbially Induced Calcite Precipitation (MICP)}

Biomineralizationisaprocessin which organisms produce/ precipitate minerals. In nature, mineral precipitation may occur through two different mechanisms: biologically controlled mineralization (BCM) or biologically induced mineralization (BIM) (Lowenstan \& Weiner, 1989).

$\mathrm{BCM}$, is a controlled process by the organism in terms of nucleation, and up growth of the mineral particles and these synthesized minerals, to a large extent, are specific to the species involved but independent from environmental conditions (De Muynck et al., 2010b). Magnetite formation in magnetotactic bacteria and silica deposition in diatoms could be given as an example of such a controlled mineralization process (Barabesi et al., 2007; Bazylinski et al., 2007).

On the other hand, $\mathrm{CaCO} 3$ production by bacteria is usually considered to occur as a result of BIM or MICP rather than BCM. In MICP produced mineral is dependent on environmental conditions to a higher degree (Ben Omar et al., 1997; Rivadeneyra et al., 1994) and there is no specific mechanism thought to be related with this process (Barabesi et al., 2007). According to several studies, bacterial species and abiotic factors such as salinity and $\mathrm{pH}$ are critically involved in calcium carbonate precipitation in different ways (Knorre \& Krumbein, 2000; Rivadeneyra et al., 1994). In this process, bacterial bodies can be embedded within the layers of growing calcium carbonate precipitates on their external surfaces (Fig. 1).

There are four interrelated key factors involved in calcium carbonate precipitation by MICP (Castanier et al., 1999; Hammes et al., 2003).

1. calcium concentration: necessary to bond with carbonate ions in the calcite mineral production

2. concentration of dissolved inorganic carbon (DIC): availability of $\mathrm{HCO}_{3}-$ and $\mathrm{CO}_{3}^{2}$ - is crucial to establish bicarbonate-carbonate equilibrium

3. $\mathrm{pH}$ : best at 8 to 9

4. availability of nucleation sites: necessary as a binding zone with divalent cations as $\mathrm{Ca}^{2+}$

When the effective concentration of calcium and carbonate ions exceeds the solubility constant $\left(\mathrm{K}_{\mathrm{so}}\right)$, the system becomes oversaturated (the saturation state is depicted as $\Omega$ ) and calcium carbonate precipitation takes place (Eqs. (1) and (2)) (Morse, 1983).

$\mathrm{Ca}^{2+}+\mathrm{CO}_{3}^{2-} \rightleftharpoons \mathrm{CaCO}_{3}$

$\Omega=\mathrm{a}\left(\mathrm{Ca}^{2+}\right) \mathrm{a}\left(\mathrm{CO}_{3}^{2-)} / \mathrm{K}_{\text {so }}\right.$ with $K_{\text {so calcite }, 25^{\circ}}=4,83 \times 10^{-9}$

\section{MICP Use In Conservation Treatments}

First studies to understand the possible roles of biological organisms in calcite formations date back to 1910. Especially in 1968 studies on the role of microorganisms on geological and geochemical processes gained

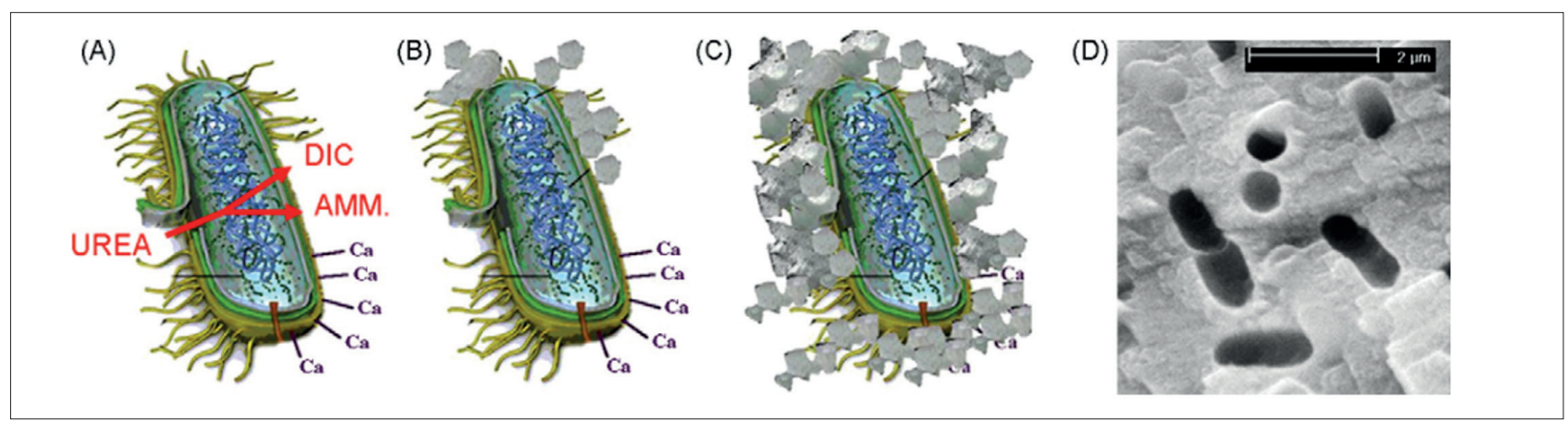

Figure 1: Illustration of MICP process with urea hydrolysis. With the addition of urea to the microenvironment of bacteria, dissolved inorganic carbon (DIC) and ammonium (AMM) are released in the micro- environment of the bacteria (A). In the presence of calcium ions, this can result in a local supersaturation and hence heterogeneous precipitation of calcium carbonate on the bacterial cell wall having negative nature (B). After some time, bacterial body becomes encapsulated (C) and due to decrease in nutrient transfer, cell death occurs. Image (D) represents the imprints of bacterial bodies surrounded by calcium carbonate precipitation (De Muynck et al., 2010a). / Üre hidrolizi ile mikrobiyal kalsiyum karbonat çökelme sürecinin gösterimi. Bakterinin mikro çevresine üre ilave edilmesi ile çözünmüş inorganik karbon ve amonyum bu çevreye salınmaktadır (A). Kalsiyum iyonları varlığında, bu durum bölgesel asırı doygunluğa sebep olarak negatif özellikteki hücre duvarında heterojen kalsiyum karbonat presipitasyonunu meydana getirmektedir (B). Bu esnada bakteri gövdesi kapsüllenir (C) ve besin transferindeki azalma sebebiyle hücre ölümü gerçekleşmektedir. Şekil (D), kalsiyum karbonat çökeltisi ile çevrili bakteri gövdelerinin izlerini temsil etmektedir (De Muynck vd., 2010a). 
momentum with the emergence of the multidisciplinary field "geomicrobiology" (Personal notes of Orial, 2010). In relation to these developments, Boquet et al. (1973) and Adolphe and Billy (1974) showed the role of certain soil-originated bacterial species in calcium carbonate precipitation while other scientists had focused their studies on marine microorganisms' role in the precipitation of calcium carbonate (Drew, 1911; Shinano, 1972). Based on these results, several Bacillus species and Pseudomonas aeruginosa were specifically shown to precipitate calcium carbonate on solid media (B4). Authors had also reported that crystal precipitation was largely affected by the content of the medium and environmental conditions $(\mathrm{pH}$, temperature), and when the optimum conditions were provided, numerous bacteria could precipitate calcium carbonate. Besides, Castanier (1987) wrote a $\mathrm{Ph}$. D. thesis on the terms and processes of bacterial carbonatogenesis which gave insight about the role of bacterial carbonatogenesis in the biogeological history of our planet (Castanier, 1987). Soon after, in 1990, a patent titled "Procedure for the biological treatment to artificial surfaces" was filed by Calcite Bioconcept - a company specialized on $\mathrm{BM}$ and biomineralization applications, for the utilization of carbonate precipitating bacteria for the protection of surfaces.

In the following years, Le Métayer-Levrel et al. (1999) made significant progress in the production and application process of the biomineralization technique through a collaboration between the Calcite Bioconcept, the University of Nantes, and the Historical Monuments Research Laboratory (LRMH, www.lrmh.fr). In this study, researchers isolated various bacteria from natural carbonate producing environments and tested their ability and performance to precipitate calcium carbonate. Bacillus cereus had been selected to be used in biomineralization treatments based on its high $\mathrm{CaCO} 3$ precipitation with a yield of $0.6 \mathrm{~g} \mathrm{CaCO} 3 \mathrm{~g}$ per $\mathrm{g}$ organic matter (Castanier et al., 1999). The nutrient medium had also been optimized for its protein and nitrate content to trigger the production of carbonate through nitrogen cycle metabolic pathways and for the financial cost of the ingredients. Moreover, a fungicide had also been added to prevent fungal growth on the stone (Orial et al., 2003). In these studies applications were conducted on miniature walls of either fine-grained (high porosity, small pores) and coarse-grained limestone (variable porosity, large pores), and red brick walls as a control to be able to differentiate microbial calcite formation from fossilized bacterial bodies naturally occurring in limestone. Specifically, in this technique, a bacterial culture had been sprayed onto the target area, and fed for 5 continuous days by spraying nutrients every $24 \mathrm{~h}$ or $48 \mathrm{~h}$, depending on the type of the stone. This application creates a microbial calcite coating - the "biocalcin". Layers of fossilized bacteria in the form of calcite are shown in Figure 2 after 5 days of treatment (Le MétayerLevrel et al., 1999).

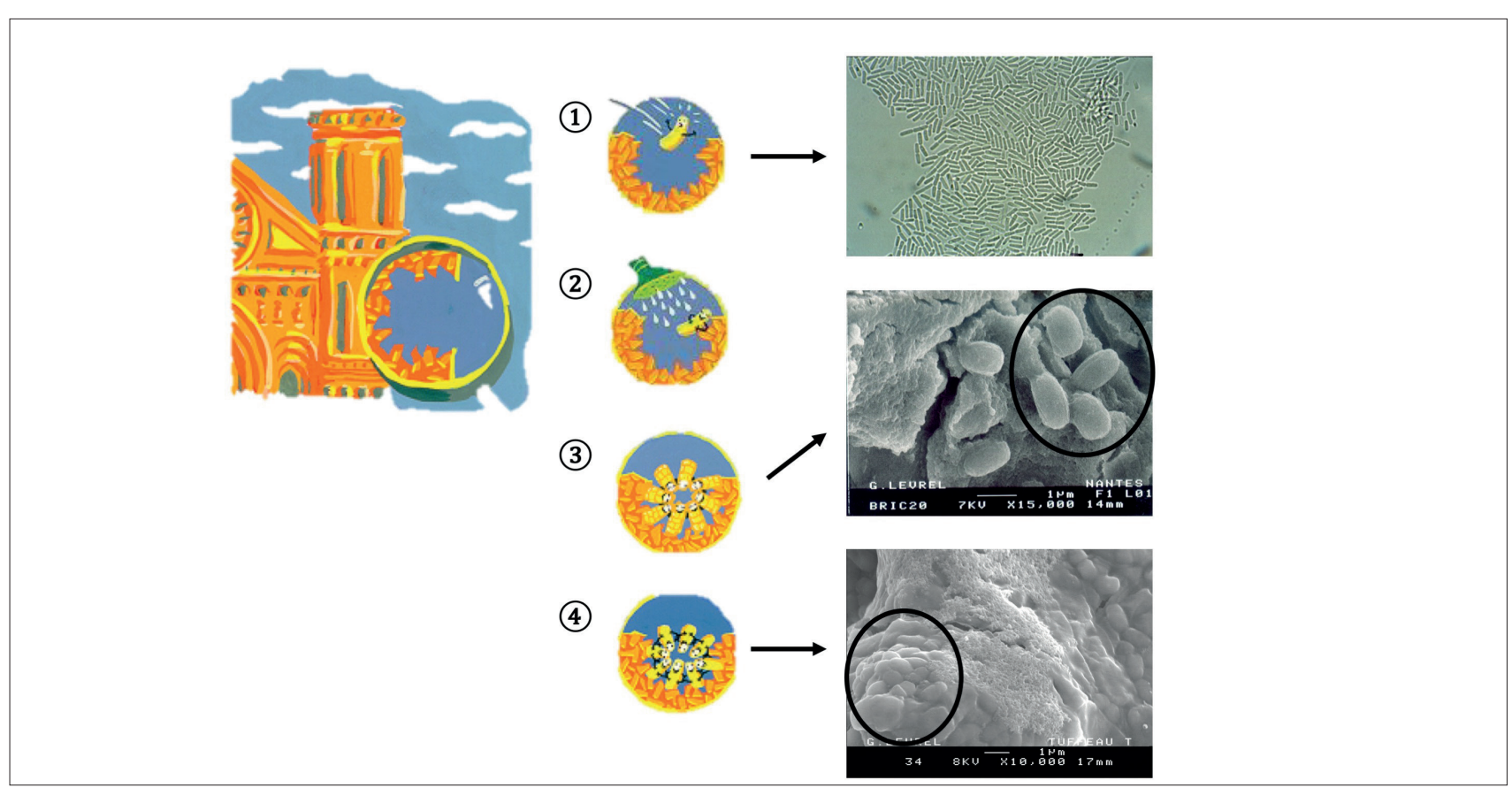

Figure 2: Illustration of the biomineralization treatment: (1) Spraying of bacteria onto the stone surface, optical microscope view of $B$. cereus culture (Magnification x 1000) (2) Spraying of the nutritional medium, (3) Bacterial multiplication, SEM view of $B$. cereus in the carbonatogenesis phase, the $\mathrm{CaCO}_{3}$ cocoons are clearly visible (4) Formation of calcite crystals, SEM view of the superposed layers of fossilized bacteria forming a calcite coating (Personal notes of Orial, 2010). / Biyomineralizasyon gösterimi: (1) Taş yüzeyine bakteri püskürtülmesi, B. cereus hücrelerinin mikroskop görüntüsü (1000X büyütme) (2) Besleyici solüsyonun püskürtülmesi, (3) Bakterilerin büyümesi, karbonatogenezis fazında B. cereus'un SEM görüntüsü (4) Kalsit kristallerinin oluşumu; kalsit tabakasını oluşturan fosilleşmiş bakterilerin üst üste binmiş katmanlarının SEM görüntüsü (Orial'in kişisel notlarl, 2010). 
After these initial studies, in 1993 further tests were conducted in situ to assess the performance of this bacterium in outdoor conditions on the tower of the Saint Medard Church (France), constructed by Tuffeau limestone. In this study, biomineralization treatment was performed on an area of $50 \mathrm{~m} 2$, and assessed 6 and 12 months after the application. Performance evaluation of the treatment was conducted by several techniques such as SEM analysis, counting of bacterial populations, macroscopic observation, imprint molding, measurement of surficial permeability, and colorimetry. Based on these measurements, biomineralization treatment was shown to create microbial calcite as a protective layer reducing water absorption (with a $1 / 5$ ratio) on the applied area at the same time allowing water vapor permeability through the original material. Moreover, B. cereus culture had prevented the unwanted growth of autochthonous acidifying bacterial populations on stone (Le Métayer-Levrel et al., 1999). After 10 years of this biomineralization treatment, SEM analysis showed that the durability of the microbial calcite layer was changing depending on its location on the stone and the orientation of the facade. Indeed, the aging of the microbial coat and the original stone surface had been alike, revealing the compatibility of the created layer with the original material. Consequently, based on these findings, due to cracking of the microbial calcite coat (biocalcin), it was concluded that this treatment must be renewed at certain intervals to fulfill its protective role (Orial et al., 2003).

Various research groups have also studied biomineralization techniques for the conservation of historical monuments. In Italy, Tiano et al. (1999) used Micrococcus spp. (isolated from a monument) and Bacillus subtilis (from a culture type collection) strains to form a microbial mineral layer on Pietra di Lecce bioclastic limestone. In this method, stone specimens were inoculated with an overnight culture of each strain; then bacterial culture suspensions were applied on the upper surface of each stone. Afterward, deposited bacteria were fed by wetting the samples daily for 15 days. According to the authors, the treatment had negative consequences on monumental stones, such as presence of products of new formation and formation of stained patches by air-borne fungi. To overcome these problems, authors suggested the use of polypeptides, based on previous work by Tiano (1995), to better control the growth of calcium carbonate precipitation in the pores of the stone. This study was about using organic matrix macromolecules (OMM) extracted from Mytilus californianus (a mollusc) shells to promote calcite precipitation within the stone pores. Though porosity and water absorption were decreased (Tiano, 1995), practical application was hindered due to the impracticality of the procedure (Tiano et al., 1999). Therefore, the authors proposed similar functionalized proteins such as polyaspartic acid to control the nucleation and development of calcium carbonate precipitation within the pores of weathered calcareous stones and they managed to control the growth pattern of calcite crystals on those stones by using polyaspartic acid (Tiano et al., 2006). This method was found to be promising for the protection and conservation of marble statues and objects of high aesthetic and artistic value.

In Spain, Rodriguez-Navarro et al. (2003) used Myxococcus xanthus for the consolidation of limestone surfaces. In their study, noteworthy results were achieved when the M. xanthus had been applied to bioclastic calcarenite cubes. It was reported that bacteria induced calcium carbonate precipitation on the walls of pores without plugging them (Rodriguez-Navarro et al., 2003). However, it was also stated that improvement in the culture media composition and creation of $\mathrm{M}$. xanthus mutants, displaying high carbonatogenic yield, consolidation treatment could have performed better on applied areas.

Further promising results, over the last two decades, in biomineralization applications have been encouraging researchers to use microbial carbonate approaches for the conservation of historic calcareous stones (Barabesi et al., 2007; Delgado Rodrigues \& Ferreira Pinto, 2019; Perito et al., 2014).

\section{BIOLOGICAL MORTAR (BM) TECHNIQUE}

Biological mortar is a mixture of stone powder (aggregate), bacterial sediment (binder), and feeding solution (necessary water to form the paste). The treatment is referred as "biological mortar" due to its binder being of bacterial origin. In theory, the feeding solution provides necessary elements to bacteria for the biochemical process of MICP. The produced calcite minerals bind the aggregates of stones through nucleation, and proliferation on the surface and between the aggregates in mortar.

As previously mentioned, the BM technique had been inspired from the MICP process and developed by the Calcite Bioconcept over the years. In 2003, Orial et al. (2003) advanced the BM manufacturing process for healing cracks and fixing scales of historic calcareous stones. This study involved feasibility tests, and the optimization process of the three main components of mortar: the stone powder (Tuffeau powder, constituent of the Argenton-Chateau), feeding solution of bacteria, bacterial sediment composed of Bacillus cereus. In addition to the adjustment of constituents and their proportions, several trials were also conducted to achieve the desired balance between the components of BM to obtain a cohesive mortar. BM treatment procedure and 


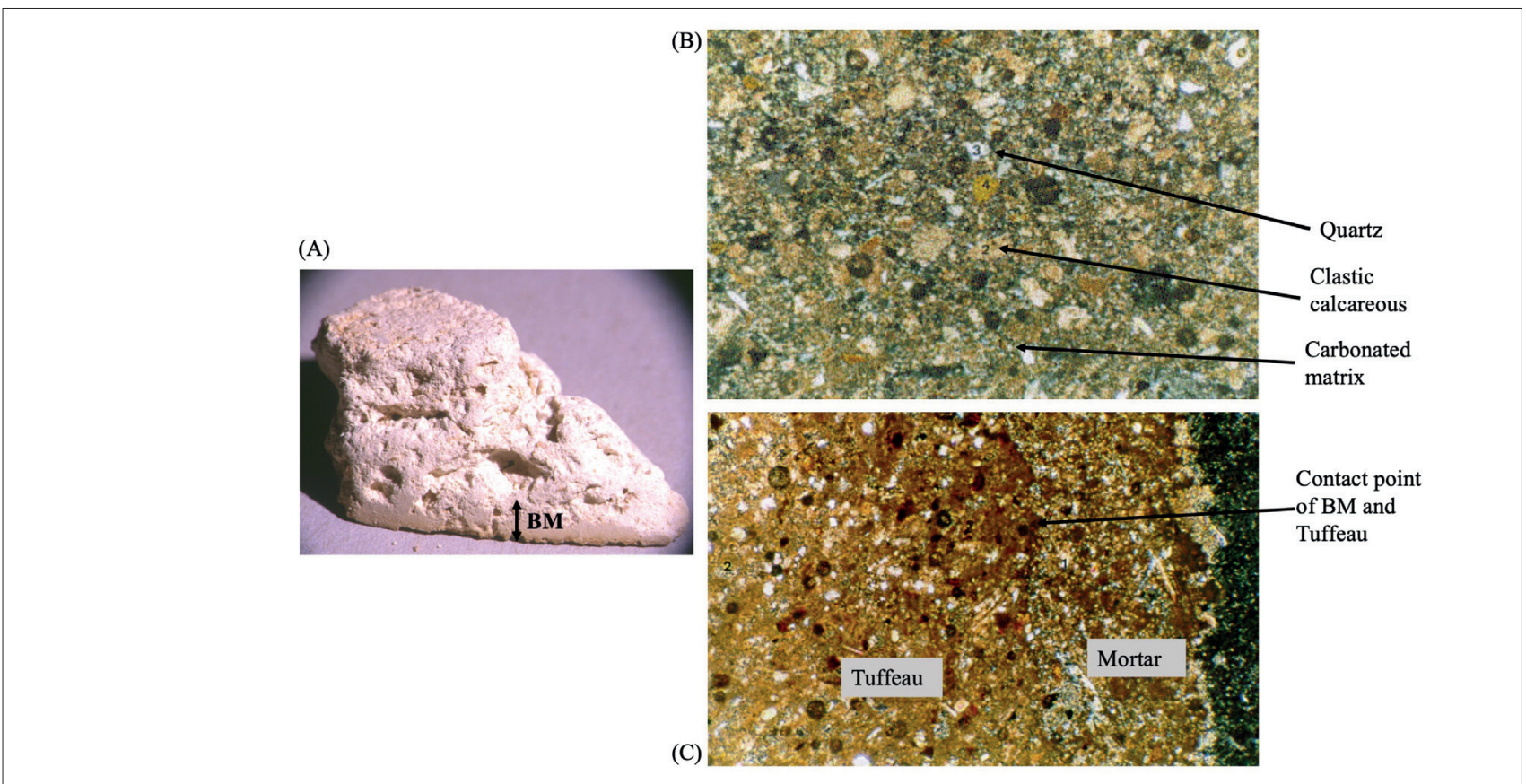

Figure 3: (A) Appearance of BM applied to a fragment of Tuffeau (B) General texture of BM (C) BM and Tuffeau bonding zone (Orial et al., 2003). I (A) Biyolojik harç uygulanan Tuffeau parçasının görünümü (B) Biyolojik harcın genel dokusu (C) Biyolojik harç ve tüf bağlanma bölgesi (Orial vd., 2003).

application areas were also defined considering the current state of the building where in situ applications were planned. Developed BM was examined by using a light microscope, and SEM and evaluated based on several criteria such as aspect, color, bleeding, microcracking, and resistance to fracture. Based on their results, the proportion of BM components was defined as 1 part bacterial sediment, 1 part feeding solution, and 2 parts stone powder. More specifically, the best results were obtained with bacterial sediment including $10^{9}$ $\mathrm{CFU} / \mathrm{ml}$ and limestone powder granulometry between 40 and $160 \mu \mathrm{m}$ (Orial et al., 2003).

Based on optical microscope observations, BM showed a homogenous and fine micro-porous structure as the original material, Tuffeau. Moreover, matrix constituents of BM were also similar to those of Tuffeau. Developed BM also showed a cohesive character by strongly binding to its matrix and grains (Fig. 3). Based on SEM observations, the Tuffeau was found to be composed of calcium carbonate, quartz, and cristobalite microspheres similar to BM. Indeed, cross-sections of the mortar/stone interface had presented a good and continuous contact (Orial et al., 2003).

After these preliminary works in the laboratory, the developed BM had been applied on a portal of the church of Argenton-Château (France). The church was built with a soft limestone, Tuffeau. Since the sculpture of this portal had been badly damaged due to severe climatic conditions, a conservation and restoration project was needed for the consolidation of the scales and flakes in addition to filling up cracks. BM had been applied by using a spatula, a brush, or a syringe, being careful not to break the bacterial bodies that are still alive. The conservation and restoration project of the church of Argenton-Château was finished in 2000 (Fig. 4). Since the precipitated mineral was similar to the mineral component of the original material, biological mortar worked in harmony with the applied material with no difference in color and texture (Orial et al., 2003). Two years after completion, in 2002, based on visual examinations, treated areas showed that everything was in good condition (Orial et al., 2003).

Since these initial studies of Orial et al. (2003), BM based micro-crack remediation of historic calcareous stones was studied only by a limited number of research groups (Minto et al., 2018; Sırt Çıplak, 2018).

Within the framework of a national project (TUBITAK-1001/Project code: 115M188) and a Ph.D. study, Sırt-Çıplak (2018) worked on BM for microcrack $<1 \mathrm{~mm}$ remediation in travertine monuments. To this end, a field study was carried out in thermal spring water resources in Pamukkale Travertines (Denizli/ Turkey) to isolate potential bacterial species. Among isolated strains, Bacillus cereus, already known to have high calcite production capacity, was selected to constitute the bacterial sediment component of BM. Optimization of each component (bacterial sediment, feeding solution, stone powder) and their proportions 

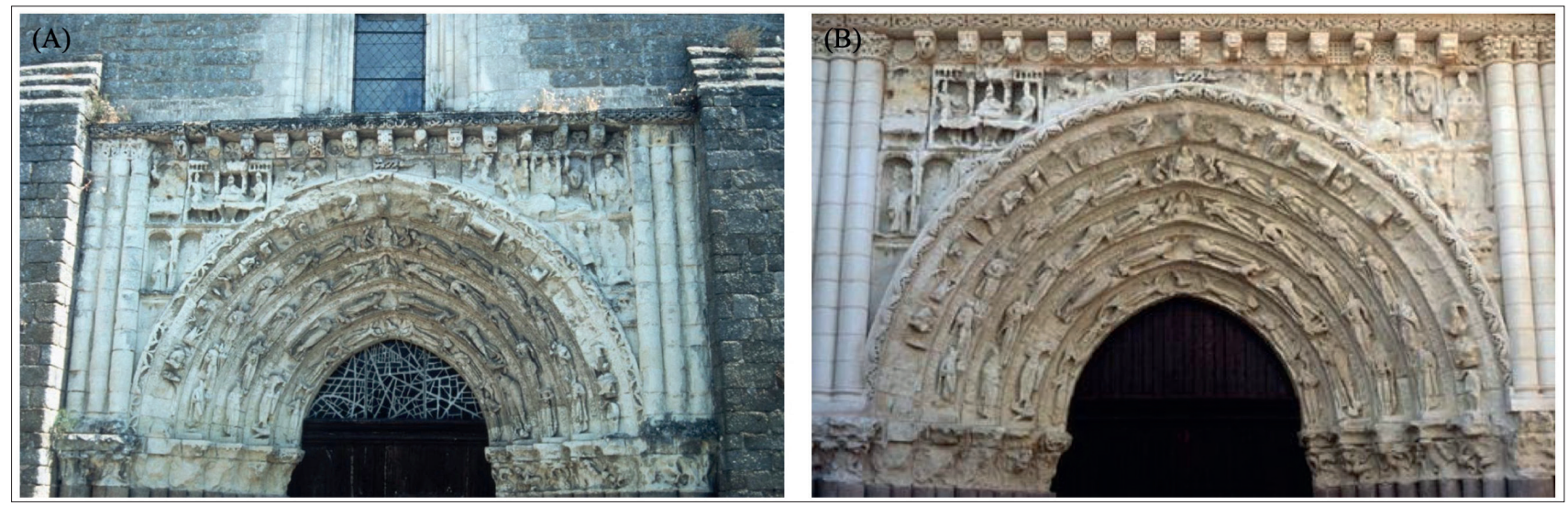

Figure 4: Portal of the church of Argenton-Château before (A) and after BM application (B) (Orial et al., 2003). / Argenton-Château kilisesinin portall, biyolojik harç uygulamasindan önce (A) ve sonra (B) (Orial et vd., 2003).

in BM were performed simultaneously. Best results were obtained when bacterial sediment was comprised of $10^{8} \mathrm{CFU} / \mathrm{ml}$ and granulometry of stone (travertine) powder was in the range of 38-150 $\mu \mathrm{m}$. Content and concentration of feeding solution were prepared with the help of the formula of Orial et. al (2003). Molded and hand-shaped $\mathrm{BM}$ presented their best at 1 part bacterial sediment, 1 part feeding solution, and 5 part stone powder based on microstructural analyses and other evaluation criteria conducted under laboratory conditions. Upon specifying all components of BM in detail, mortar set-up was performed in defined proportions and applied to micro-cracks of artificially aged test stones under laboratory and open-air conditions. Optical microscope analyses of BM applied test stones showed secondary calcite formation in their micro-cracks. Based on stereomicroscope images, it was reported that a strong bond was generated between the grains and matrix of BM. Besides showing such similar textures, the interface of biological mortar and rock surface seemed to be continuous and coherent in all treated samples (Fig. 5).

In this study, when SEM- EDX analysis was conducted on BM cubes, entombment of B. cereus bodies (endospores) was observed in microbial carbonate stratification. This indicated B. cereus had fulfilled its role as a binder for stone aggregates in BM (Fig. 6). Moreover, based on evaluation criteria such as crack formation, fungal growth, material integrity and etc., developed BM was acceptable.

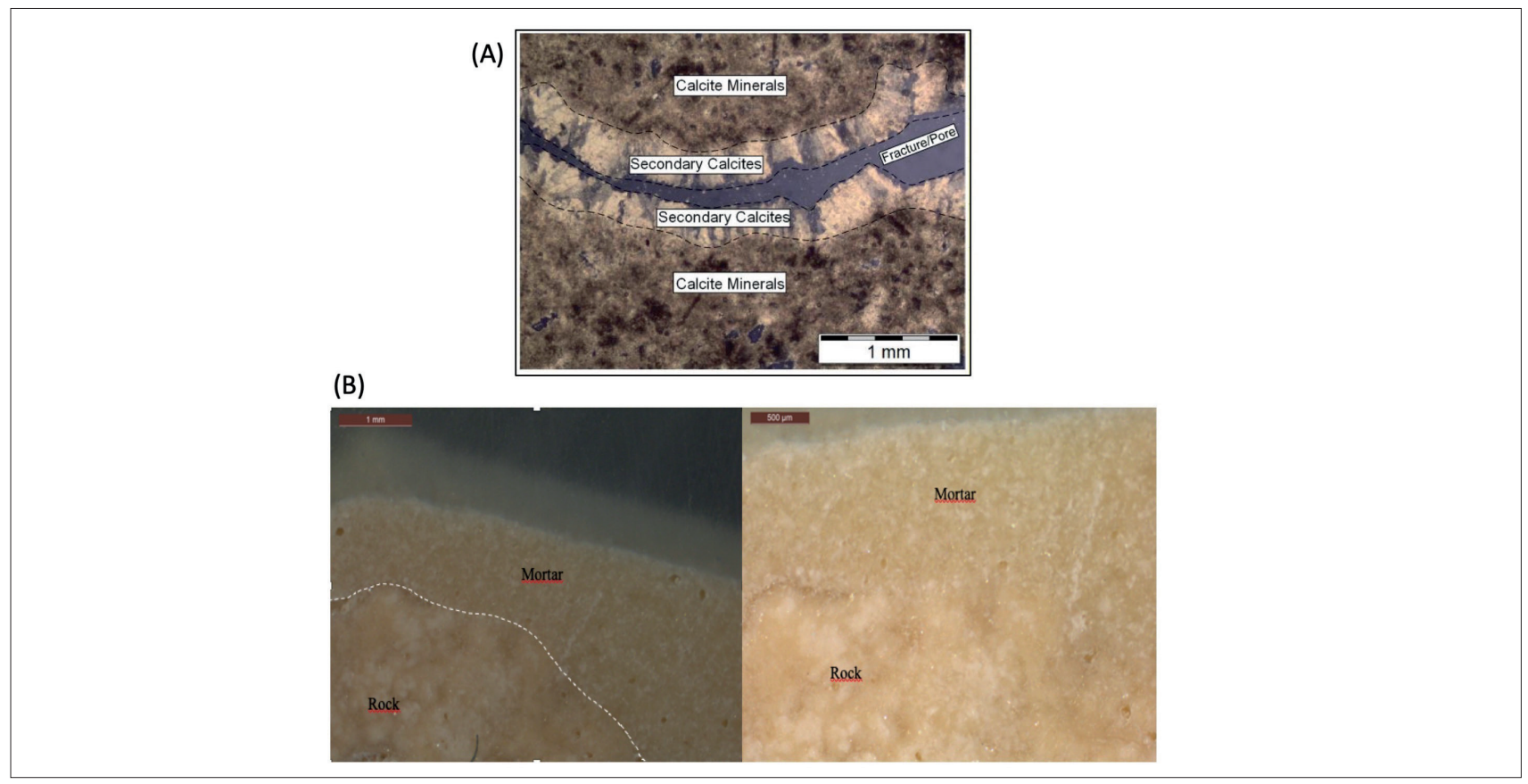

Figure 5: (A) Thin section analyses of BM in micro-cracks of test stones by optical microscope (B) Cross section analyses of BM applied travertine by stereomicroscope / (A) Test taşlarının çatlaklarındaki biyolojik harcın ince kesitinin optik mikroskop ile analizi. (B) Biyolojik harç uygulanan travertenin kalın kesitinin stereo mikroskop ile analizi (Sırt Çıplak, 2018). 


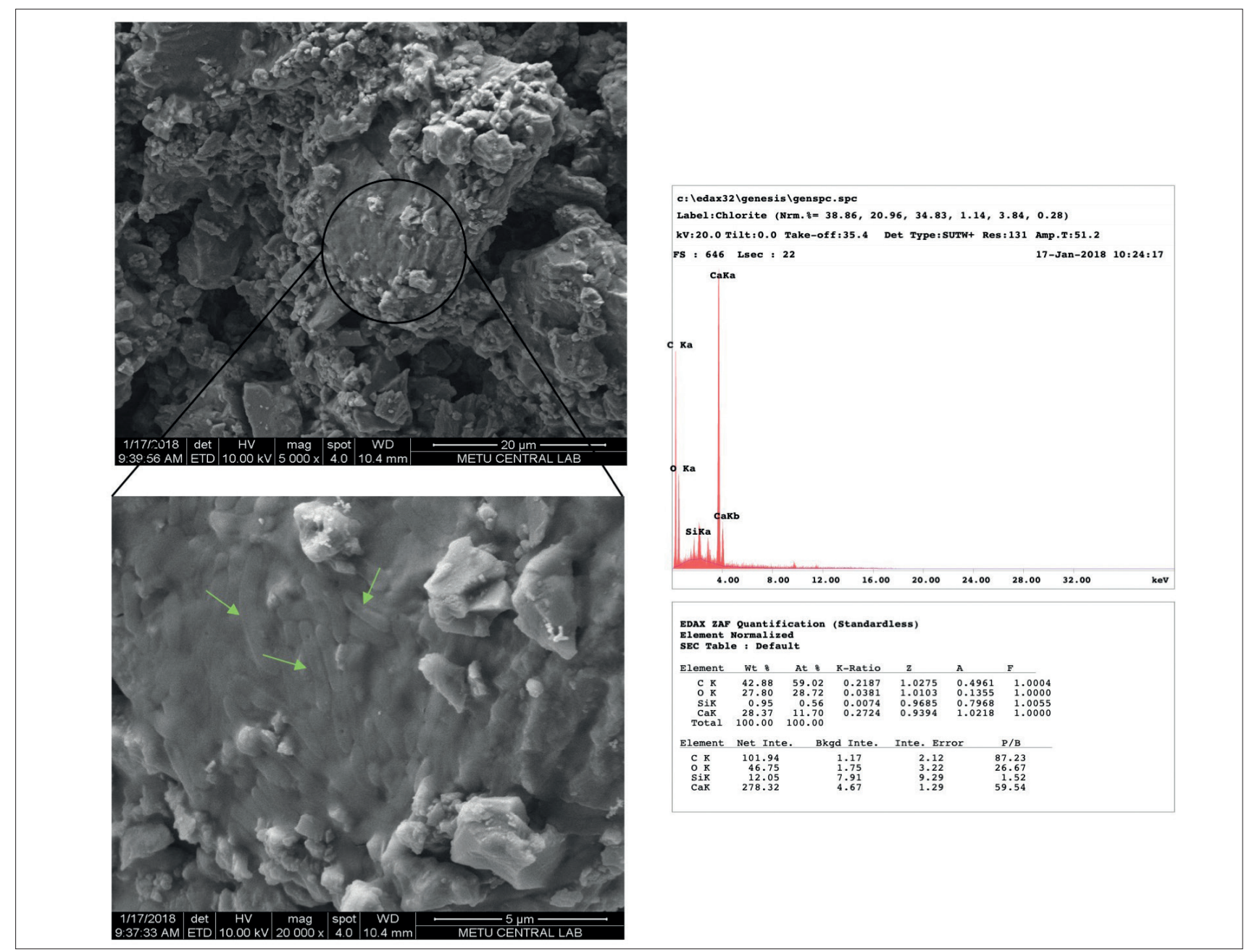

Figure 6: SEM-EDX analysis of BM after curing for 28 days. Green colored arrows show embedded bacterial bodies / 28 gün inkübasyondan sonra biyolojik harcın SEM-EDX ile analizi. Yeşil oklar gömülü bakteri gövdelerini göstermektedir (Sirt Çılak, 2018).

In another study, Minto et al. (2018) used Sporocarsina pasteurii (DSMZ-German Collection) for its ability to precipitate calcite. In their settings, instead of applying bacterial paste directly, they first filled the cracks with large marble grains $(0.5-1.4 \mathrm{~mm})$ and then used microbial mortar as binding agent. X-ray computed tomography (X-CT) was used to examine MICP distribution throughout the column filled with marble grains. To understand the changes during reagent transport as a result of $\mathrm{CaCO} 3$ precipitation, fluid transport properties and the porosity of the grouted marble were also predicted using tracer tests. Consequently, authors reported that cracks in weathered marble could be healed by first introducing marble grains, then calcifying bacteria culture and cementing solution into the cracks of the stone (Minto et al., 2018).

\section{CHALLENGES AND FUTURE WORK}

Remediation of micro-cracks with BM addresses the shortcomings of conventional methodologies, however there are also a few limitations. BM is an environmentally friendly green repair material, but depending on its biological origin, changes in environmental conditions and factors (rain, wind, temperature, $\mathrm{pH}$, nutrients etc.) can largely affect the microbial activity and likewise MICP. Therefore, the recommended season for a BM application in the field should be during a mild season having a minimum daily temperature of $15^{\circ} \mathrm{C}$, a maximum daytime temperature difference of $10^{\circ} \mathrm{C}$, low rain, little wind, and an average level of humidity.

Using environmental strains rather than type culture collection limits the rate of bacterial calcite precipitation, which in turn effects the self-healing properties of BM. Therefore, the amount of $\mathrm{CaCO} 3$ precipitation could be increased by improving the parameters in the experimental procedure of the BM. This could be 
achieved by adding specific enzymes or macromolecules to induce nitrogen cycle pathways in feeding solution, using multiple bacterial assembles to trigger/increase the amount of calcite production, identification of the genes related with the mineral production process, and the adjustment of these genes to bring out large quantities of macromolecules that might induce calcite precipitation.

Due to yielding limited quantities of bacteria from environmental samples, at present, BM could only be used in the protection and conservation of calcareous stones of high aesthetic and artistic value. Using bioreactors to increase the production of bacterial culture could pave the way for large-scale applications.

Even if bacterial strains used in BM were isolated from natural carbonate-producing environments; unpredictable changes in bacterial culture and feeding solution may be of concern in the long term. However, this could be addressed by defining the whole procedure including regular control with the contribution of a multidisciplinary team composed of conservation architects, geological engineers, physicists, microbiologists, and restorers as well.

\section{CONCLUSION}

Pioneering applications of the biomineralization approach through microbially induced calcite precipitation firstly emerged in the field of cultural heritage conservation. However, there are still few studies on the micro-crack remediation of historic calcareous stones using biological mortars (BM) while biomineralization approach has been widely used in contemporary building materials.

In current studies, it has been shown that BMs, developed through a process mimicking the natural calcareous stone formation, represented a compatible and quite similar structure with the original stone. Based on these researches, BM technology developed for remediation of micro-cracks was found to be feasible for the protection and conservation of historic calcareous stones of high value. In addition, as bacterial species used in BM can easily be obtained from local renewable resources, the raw material is always available.

Despite its high potential as an environmentally friendly and compatible material, there is still much to investigate and improve both in the production, and application methodologies to transfer this repair material from laboratory to field. Consequently, considering shortcomings of conventional methods, improvement of BM applications or development of novel approaches for the micro-crack bioremediation of stones are needed for future interventions in cultural heritage.

\section{REFERENCES}

ABD EL AAL, A. (2017).

Identification and characterization of near surface cavities in Tuwaiq Mountain Limestone, Riyadh, KSA, "detection and treatment". Egyptian Journal of Petroleum, 26(1), 215-223. https://doi.org/10.1016/j. ejpe.2016.04.004

ADOLPHE, J. P., LOUBIERE, J. F., PARADAS, J., \& SOLEILHAVOUP, F. (1990).

Procédé de traitement biologique d'une surface artificielle.

ANNAMALAI, S. K., ARUNACHALAM, K. D., SATHYANARAYANAN, K. S., \& KUMAR, V. R. (2013). Characterization and Applications of Biocement Enchanced with Carbon Nanotubes for Improved Remediation on Cracked Concrete Structures. Asian Journal of Chemistry, 25, S143-S146.

BARABESI, C., GALIZZI, A., MASTROMEI, G., ROSSI, M., TAMBURINI, E., \& PERITO, B. (2007). Bacillus subtilis Gene Cluster Involved in Calcium Carbonate Biomineralization. Journal of Bacteriology, 189(1), 228-235. https://doi.org/10.1128/JB.01450-06

BAZYLINSKI, D. A., FRANKEL, R. B., \& KONHAUSER, K. O. (2007).

Modes of Biomineralization of Magnetite by Microbes. Geomicrobiology Journal, 24(6), 465-475. https://doi. org/10.1080/01490450701572259

BEN OMAR, N., ARIAS, J. M., \& GONZÁLEZMUÑOZ, M. T. (1997).

Extracellular bacterial mineralization within the context of geomicrobiology. Microbiologia, 13(2), 161-172.

BÖKE, H., ÇIZER, Ö., İPEKOĞLU, B., UĞURLU, E., ȘERIFAKI, K., \& TOPRAK, G. (2008). Characteristics of lime produced from limestone containing diatoms. Construction and Building Materials, 22(5), 866-874. https://doi.org/10.1016/j.conbuildmat.2006.12.010

BOQUET, E., BORONAT, A., \& RAMOS-CORMENZANA, A. (1973).

Production of calcite (Calcium carbonate) crystals by soil bacteria is a general phenomenon. 
BORSOI, G. (2017).

Nanostructured lime-based materials for the conservation of calcareous substrates. A+BE | Architecture and the Built Environment.

CARTWRIGHT, T. A., VERGÈS-BELMIN, V., \& INTERNATIONAL SCIENTIFIC COMMITTEE FOR STONE (EDS.). (2008).

Illustrated glossary on stone deterioration $=:$ Glossaire illustré sur les formes d'altération de la pierre. ICOMOS.

CASTANIER, S. (1987).

Microbiogeologie: Processus et modalites de la carbonatogenese bacterienne.

CASTANIER, S., LE MÉTAYER-LEVREL, G., \& PERTHUISOT, J.-P. (1999).

Ca-carbonates precipitation and limestone genesisThe microbiogeologist point of view. Sedimentary Geology, 126(1-4), 9-23. https://doi.org/10.1016/S00370738(99)00028-7

CASTRO-ALONSO, M. J., MONTAÑEZ-HERNANDEZ, L. E., SANCHEZ-MUÑOZ, M. A., MACIAS FRANCO, M. R., NARAYANASAMY, R., \& BALAGURUSAMY, N. (2019).

Microbially Induced Calcium Carbonate Precipitation (MICP) and Its Potential in Bioconcrete: Microbiological and Molecular Concepts. Frontiers in Materials, 6, 126. https://doi.org/10.3389/fmats.2019.00126

DE MUYNCK, W., DE BELIE, N., \& VERSTRAETE, W. (2010a).

Microbial carbonate precipitation in construction materials: A review. Ecological Engineering, 36(2), 118-136. https://doi.org/10.1016/j.ecoleng.2009.02.006

DELGADO RODRIGUES, J., \& FERREIRA PINTO, A. P. (2019).

Stone consolidation by biomineralization. Contribution for a new conceptual and practical approach to consolidate soft decayed limestones. Journal of Cultural Heritage, 39, 82-92. https://doi.org/10.1016/j.culher.2019.04.022

DOEHNE, E. F., PRICE, C. A., \& GETTY CONSERVATION INSTITUTE. (2010).

Stone conservation: An overview of current research. Getty Conservation Institute.
DREW, G. H. (1911).

The action of some denitrifying bacteria in tropical and temperate seas, and bacterial precipitation of calcium carbonate in the sea. J. Mar. Biol. Ass., 9, 142-155.

GÜÇHAN, N. Ș. (2018).

Tarihi Kireçtaşların Koruma Müdahalelerinde Uygulamak Üzere Kalsit Üreten Bakterilerle Biyolojik Harç Geliştirilmesi Program Kodu: 1001 Proje No: 115 M188 (p. 110). https:// app.trdizin.gov.tr/publication/project/detail/TWpBek9UZzQ

HAMMES, F., BOON, N., DE VILLIERS, J., VERSTRAETE, W., \& SICILIANO, S. D. (2003).

Strain-Specific Ureolytic Microbial Calcium Carbonate Precipitation. Applied and Environmental Microbiology, 69(8), 4901-4909. https://doi.org/10.1128/ AEM.69.8.4901-4909.2003

HANSEN, E., DOEHNE, E., FIDLER, J., LARSON, J., MARTIN, B., MATTEINI, M., RODRIGUEZ-NAVARRO, C., PARDO, E. S., PRICE, C., DE TAGLE, A., TEUTONICO, J. M., \& WEISS, N. (2003).

A review of selected inorganic consolidants and protective treatments for porous calcareous materials. Studies in Conservation, 48(sup1), 13-25. https://doi.org/10.1179/ sic.2003.48.Supplement-1.13

JAGADEESHA KUMAR, B. G., PRABHAKARA, R., \& PUSHPA, H. (2013).

Effect of Bacterial Calcite Precipitation on Compressive Strength of Mortar Cubes.

JONKERS, H. M. (2011).

Bacteria-based self-healing concrete. Heron, 56(1/2), $1-12$.

JROUNDI, F., GONZALEZ-MUÑOZ, M. T., \& RODRIGUEZ-NAVARRO, C. (2021).

Protection and Consolidation of Stone Heritage by Bacterial Carbonatogenesis. In E. Joseph (Ed.), Microorganisms in the Deterioration and Preservation of Cultural Heritage (pp. 281-299). Springer International Publishing. https://doi.org/10.1007/978-3-030-69411-1_13

KLISIŃSKA-KOPACZ, A., TIŠLOVA, R., ADAMSKI, G., \& KOZŁOWSKI, R. (2010).

Pore structure of historic and repair Roman cement mortars to establish their compatibility. Journal of Cultural Heritage, 11(4), 404-410. https://doi.org/10.1016/j.culher.2010.03.002 
KNORRE, H., \& KRUMBEIN, K. E. (2000).

Bacterial calcification. 25-31.

LE MÉTAYER-LEVREL, G., CASTANIER, S., ORIAL, G., LOUBIËRE, J.-F., \& PERTHUISOT, J.-P. (1999).

Applications of bacterial carbonatogenesis to the protection and regeneration of limestones in buildings and historic patrimony. Sedimentary Geology, 126(1-4), 25-34. https://doi.org/10.1016/S0037-0738(99)00029-9

LEWIN, S. Z., \& BAER, N. S. (1974).

Rationale of the Barium Hydroxide-Urea Treatment of Decayed Stone. 13.

LOWENSTAN, H. A., \& WEINER, S. (1989). In Biomineralization. Oxford University Press.

MCNABB, K. D. (2012).

Evaluation of Consolidation Treatments for the San José Convento Column, San Antonio Missions National Historic Park, San Antonio, Texas. Theses (Graduate Program in Historic Preservation).

MINTO, J. M., TAN, Q., LUNN, R. J., EL MOUNTASSIR, G., GUO, H., \& CHENG, X. (2018).

'Microbial mortar'-restoration of degraded marble structures with microbially induced carbonate precipitation. Construction and Building Materials, 180, 44-54. https://doi.org/10.1016/j.conbuildmat.2018.05.200

MORSE, J. W. (1983).

In The kinetics of calcium carbonate dissolution and precipitation. In: Reeder, R.J. (Ed.), Carbonates: Mineralogy and Chemistry (Vol. 11, pp. 227-264). Mineralogic Society of America.

ORIAL, G., VIEWEGER, TH., \& LOUBIERE, J. F. (2003).

Biological Mortars: A Solution For Stone Sculpture Conservation. Art, Biology, and Conservation: Biodeterioration of Works of Art.

PACHECO-TORGAL, F., FARIA, J., \& JALALI, S. (2012).

Some considerations about the use of lime-cement mortars for building conservation purposes in Portugal: A reprehensible option or a lesser evil? Construction and Building Materials, 30, 488-494. https://doi. org/10.1016/j.conbuildmat.2011.12.003
PALOMO, A., BLANCO-VARELA, M. T., MARTINEZ-RAMIREZ, S., PUERTAS, F., \& FORTES, C. (2002).

Historic Mortars: Characterization and Durability. New Tendencies for Research. 21.

PERITO, B., MARVASI, M., BARABESI, C., MASTROMEI, G., BRACCI, S., VENDRELL, M., \& TIANO, P. (2014).

A Bacillus subtilis cell fraction (BCF) inducing calcium carbonate precipitation: Biotechnological perspectives for monumental stone reinforcement. Journal of Cultural Heritage, 15(4), 345-351. https://doi.org/10.1016/j. culher.2013.10.001

RAMACHANDRAN, S. K., RAMAKRISHNAN, V., \& BANG, S. S. (2001).

Remediation of Concrete Using Microorganisms. Materials Journal, 98(1), 3-9.

RIVADENEYRA, M. A., DELGADO, R., MORAL, A., FERRER, M. R., \& RAMOS-CORMENZANA, A. (1994).

Precipatation of calcium carbonate by Vibrio spp. From an inland saltern. FEMS Microbiology Ecology, 13(3), 197-204. https://doi.org/10.1111/j.1574-6941.1994. tb00066.x

RODRIGUEZ-NAVARRO, C., RODRIGUEZ-GALLEGO, M., BEN CHEKROUN, K., \& GONZALEZ-MUÑOZ, M. T. (2003).

Conservation of Ornamental Stone by Myxococcus xanthus- Induced Carbonate Biomineralization. Applied and Environmental Microbiology, 69(4), 2182-2193. https://doi.org/10.1128/AEM.69.4.2182-2193.2003

SCHUEREMANS, L., CIZER, Ö., JANSSENS, E., SERRÉ, G., \& BALEN, K. V. (2011).

Characterization of repair mortars for the assessment of their compatibility in restoration projects: Research and practice. Construction and Building Materials, 25(12), 4338-4350. https://doi.org/10.1016/j.conbuildmat.2011.01.008

SHINANO, H. (1972).

Studies of marine microorganisms taking part in the precipitation of calcium carbonate. Bull. Jpn. Soc. Sci. Fish, 38,717. 
SIRT ÇIPLAK, E. (2018).

Biological mortar application for micro-crack remediation in stones of travertine monuments. Ph. D. theses [Middle East Technical University]. http://etd.lib.metu. edu.tr/upload/12622634/index.pdf

TIANO, P. (1995).

Stone reinforcement by calcite crystal precipitation induced by organic matrix macromolecules. Stud. Conserv. 40 (3), 171-176.

TIANO, P., BIAGIOTTI, L., \& MASTROMEI, G. (1999).

Bacterial bio-mediated calcite precipitation for monumental stones conservation: Methods of evaluation. Journal of Microbiological Methods, 36(1), 139-145.

TIANO, P., CANTISANI, E., SUTHERLAND, I., \& PAGET, J. M. (2006).

Biomediated reinforcement of weathered calcareous stones. Journal of Cultural Heritage, 7.

VEIGA, M. R., VELOSA, A., \& MAGALHÃES, A. (2009).

Experimental applications of mortars with pozzolanic additions: Characterization and performance evaluation. Construction and Building Materials, 23(1), 318-327. https://doi.org/10.1016/j.conbuildmat.2007.12.003 
